\title{
Application of the Total Reflection X-Ray Fluorescence to assess mercury contamination in the sediments of the estuary of Santos, SP, Brazil
}

\author{
Torres, R.J.*; Rezende, V.N. \& Sousa, T.M. \\ Universidade Federal de São Paulo, Campus Baixada Santista, Departamento de Ciências do Mar, R. Carvalho de Mendonça, 144, \\ Encruzilhada, Santos, SP, Brazil, CEP 11070-100
}

Received December 15, 2017; Accept May 3, 2018

\begin{abstract}
For decades, the region of Baixada Santista has been undergoing an intensive process of industrialization. The area concentrates industrial activities, chemical and petrochemical companies that continuously release expressive amounts of trace metals and several organic pollutants into the ocean, and the estuarine sediments trap and store these contaminant residues. Due to its differentiated characteristics such as high bioaccumulation capacity and high toxicity at low concentrations, Mercury became the target of this study. Results obtained by Total Reflection X-Ray Fluorescence Spectrometry (TXRF) presented Hg concentrations of 0.15 to $0.77 \mathrm{mg} \mathrm{kg}^{-1}$ in the sediments of the Santos estuary, with an $88 \%$ recovery rate of Certified Sediments. The comparison with other methodologies applied in previous researches shows that this approach has proven to be compatible with previously used techniques, obtaining results consistent with the history of mercury contamination of the estuary within the last 20 years.
\end{abstract}

Key words: Contaminated sediments, Environmental contamination, Mercury, Santos Estuarine System, Technique comparison, Total X-Ray Fluorescence

\section{INTRODUCTION}

The Baixada Santista Metropolitan Region (BSMR) presents economic importance since the beginning of the colonization process. In a recent development, initiated during the 1950's, this region sheltered the first petrochemical complexes, a large industrial district and the largest port in Latin America (Bordon et al., 2011). BSMR has an important ecosystem, such as its mangrove areas used for reproduction by many species, and food, sport and artisanal fishery activities, but its estuary is directly affected by years of industrial and urban interference (Silva \& Gomes, 2012). In the past, industrial effluents were released into the estuarine system without any pretreatment, leading to decades of discharge of highly contaminated waste, by metals and persistent organic pollutants (POPs). In the 1970s, the region of Cubatão became one of the areas with the highest contamination rates due to the gases, liquid effluents and solid residues emitted from the industrial pole, registering very serious cases of public health.

The first studies to assess environmental contamination in the region, conducted by regulating agencies such as the Environmental Company of the State of São Paulo (CETESB) - linked to the Environmental Department of the State of São Paulo (SEMA) - had the concern to implement laws that regulate and control the release of toxic compounds in the environment, aiming at recovering degraded area and recuperating a more tolerable quality of life (Lamparelli et al., 2001).

Many of the industries located in the industrial complex of Cubatão use with mercury in their chemical processes, and often release it into their effluents and the estuarine system, enhancing the environmental constraints that the exposure of that metal brings. Studies carried out by CETESB since the 1970s indicate some industries as the main sources of mercury pollution, among which many continue to carry out their activities to the present day (Lamparelli et al., 2001; Silva \& 
Gomes, 2012). These studies point out 8 out of 21 industries and 8 out of 12 port terminals in the region that work with $\mathrm{Hg}$.

Mercury can be considered one of the most toxic metals in the universe of known chemical substances (Hortellani et al., 2008). This metal has a great tendency to enter organisms, bioaccumulate and biomagnify in the trophic chain, that being a major issue for a region that has a considerable part of the population working with the artisanal fishery, feeding largely from that source. Torres et al. (2015) reported bioaccumulation of $\mathrm{Hg}$ and other metals in oysters being up to $200 \%$ in this region.

Sediments have been widely used as environmental indicators because of their great capacity to incorporate and collect pollutants (Hortellani et al., 2008). Many elements may accumulate in the sediment or undergo severe reactions in accordance with environmental parameters (Torres et al., 2015). The distribution of mercury in the soil depends on the redox potential, $\mathrm{pH}$, soil type and other factors. The metallic and ionic forms present low mobility and to a larger extent can be adsorbed by different humates and minerals (Azevedo, 2003).

This study aims to evaluate mercury contamination in the Santos Estuarine System (SES), prioritizing the evaluation of recently collected sediments analyzed by Total Reflection $\mathrm{X}$-Ray Fluorescence Spectrometry. It will compare the laboratory results obtained to data from previous studies to better understand the contamination history in the area and with the CONAMA Resolution 454/2012 (CONAMA, 2012), even though this resolution relates to dredged sediments and part of this region is submitted to dredging works. Also, results are compared to specific Sediment Quality Guidelines developed for the protection of aquatic environments.

\section{MATERIALS AND METHODS}

\section{Study area and sampling}

SES is part of the BSMR and is formed by a great diversity of rivers, channels, islands and highly populated cities, and a complex of industries and port terminals surrounds it. Characterized by relatively low hydrodynamics, it receives a large contribution of sediments of continental origin (higher parts of the watercourses), thus becoming highly vulnerable to sedimentation and the accumulation of sediment-associated contaminants (Torres et al., 2009). In the upper basin, the waters of the rivers from Serra do Mar enter the estuary, giving rise to a predominance of a bidirectional flow that spreads towards the estuary driven by the tides (Young, 2017). The sediment of this region, in general, is clayey and presents a small amount of sand and silt.

The sediment samples were collected with the aid of a Petersen grab, stored in plastic bags and then transported in a thermic box at about $4^{\circ} \mathrm{C}$ to the laboratory, where they were kept in a freezer $\left(-20^{\circ} \mathrm{C}\right)$. Seven sampling stations were selected in places that had historically known concentrations of Hg: one in the port channel near the Torre Grande, one in Diana River, two in Santa Rita Long (close to the Barnabé Island), one in the Canéu's Long (close to the Bagres Island) and two in the banks along the Piaçaguera channel. Figure 1 represents the sampling area and Table 1 presents sampling coordinates.

\section{Analytical methods}

The method used for the determination and quantification of mercury in sediment samples was the principle of Total Reflection X-Ray Fluorescence Spectroscopy (TXRF), conducted by S2Picofox from Bruker. The samples were ground with the aid of a mortar and pistil since the smallersized grains aid the process of solubilization of the sample. In petri dishes, the samples were distributed and properly identified and brought to the oven at $50^{\circ} \mathrm{C}$ for approximately 48 hours. After this process, samples were divided in portions of approximately $200 \mathrm{mg}$ and subsequently placed in a falcon tube, with $2 \mathrm{~mL}$ of detergent Triton X-100 added to each. In order to quantify the elements, $10 \mu \mathrm{L}$ of Gallium (Ga) solution $1 \mathrm{~g} \mathrm{~L}^{-1}$ were added as an internal standard. Homogenization of the sample was performed by vortex for approximately 1 minute. Samples were placed in the appropriate holders for determination in the TXRF and had their multielement determined, but only $\mathrm{Hg}$ was used in the present study. As Quality Assurance, a Certified Reference Material PACS-3: Marine Sediment Reference Material

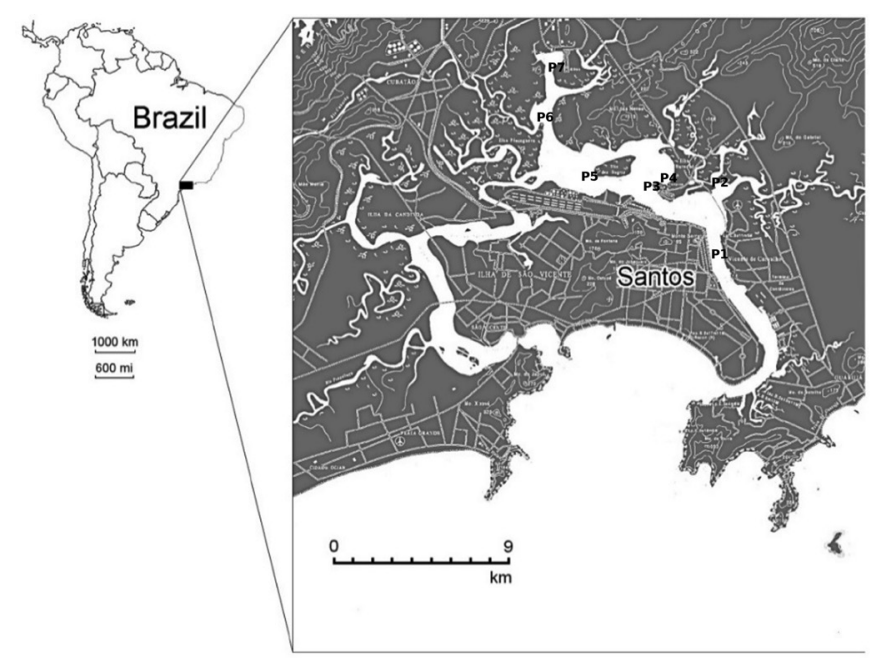

Fig. 1. Map of the Santos' estuary and the location of the sampling stations.

Table 1. Table with the geographical coordinates of the sampling stations and the respective depths of collection.

\begin{tabular}{|c|c|}
\hline Sampling stations & Depth (m) \\
\hline 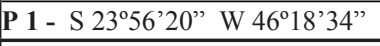 & 13.2 \\
\hline 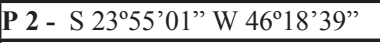 & 3.5 \\
\hline 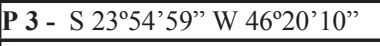 & 2.7 \\
\hline P 4 - S $23^{\circ} 54^{\prime} 53^{\prime \prime}$ W 46 $6^{\circ} 19^{\prime} 55^{\prime \prime}$ & 2.3 \\
\hline 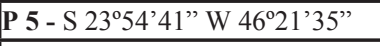 & 1.5 \\
\hline 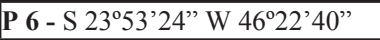 & 1.7 \\
\hline 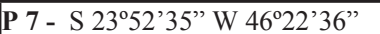 & 2.3 \\
\hline
\end{tabular}


for Trace Metals and other Constituents from the National Research Council of Canada was evaluated and an $88.2 \%$ recovery was obtained. All glassware was cleaned with Extran $^{\mathrm{TM}} 5 \%$ and decontaminated with Nitric Acid 10\%.

\section{RESULTS AND DISCUSSION}

In the present study, concentrations of $\mathrm{Hg}$ in the Santos estuarine sediments were determined at the stations specified above (Fig. 1). The CONAMA 454/2012 resolution determines two levels of $\mathrm{Hg}$ concentrations in sediments to be dredged from saline/brine environments. These concentrations regard the levels of effect of certain contaminants in aquatic organisms. Level 1 comprises concentrations equal to or greater than $0.3 \mathrm{mg} \mathrm{Kg}^{-1}$, which is related to the lower concentration or threshold effect level for aquatic organisms, while level 2 contains equal to or greater than $1.0 \mathrm{mg} \mathrm{Kg}^{-1}$ of $\mathrm{Hg}$, the concentration at which toxic effects are expected. Observing the results (Table 2 ), it was possible to understand that some stations had concentrations above those allowed by CONAMA (2012) for the first level. Station 1 (channel of the port of Santos) and station 6 (near the Island of Piaçaguera), were very close to the higher concentration on level 2 and station 3 (close to Barnabé Island) presented the concentration above level $1\left(>0.3 \mathrm{mg} \mathrm{Kg}^{-1}\right)$, whereas stations $2,4,5$ and 7 had their respective concentrations below level 1. It is important to note that, even though grain size analysis was not conducted, sediments from these regions are mainly clay with some silt and a low proportion of fine sand, and it is known that fine sediments tend to accumulate more contaminants.

CONAMA 454/2012 is intended to be used in the licensing process of dredging activities and not to deal with environmental protection. Other Sediment Quality Guidelines (SQGs) and baseline levels may be used in this case. Luiz-Silva et al. (2006) state the baseline concentration of $\mathrm{Hg}$ in the estuary is about $0.12 \mathrm{mg} \mathrm{kg}^{-1}$ while Choueri et al. (2009) established SQGs for several contaminants by this manner: places with low pollution below $0.08 \mathrm{mg}$ $\mathrm{kg}^{-1}$, moderately polluted between 0.08 and $0.32 \mathrm{mg} \mathrm{kg}{ }^{-1}$

Table 2. Comparison of the concentrations of $\mathrm{Hg}$ in sediments from the present study and those obtained by previous authors to the Santos Estuarine System.

$\begin{array}{lccccc}\begin{array}{l}\text { Sampling } \\ \text { stations }\end{array} & \begin{array}{c}\text { Present study } \\ \left(\mathrm{mg} \mathrm{Kg}^{-1}\right)\end{array} & \begin{array}{c}\text { CETESB, } \\ (2001)(\mathrm{mg} \\ \left.\mathrm{Kg}^{-1}\right) .\end{array} & \begin{array}{c}\text { Siqueira, et } \\ \text { al. }(2005) \\ \left(\mathrm{mg} \mathrm{Kg}^{-1}\right)\end{array} & \begin{array}{c}\text { Hortellani, } \\ 2008(\mathrm{mg} \\ \left.\mathrm{Kg}^{-1}\right)\end{array} & \begin{array}{c}\text { Torres et al. } \\ (2009)(\mathrm{mg}\end{array} \\ \text { P 1 } & 0.77 & - & 0.22 & 1.03 & 0.61 \\ \text { P 2 } & 0.09 & 0.37 & - & - & - \\ \text { P 3 } & 0.38 & 0.75 & - & 0.26 & - \\ \text { P 4 } & 0.15 & 0.60 & - & - & - \\ \text { P 5 } & 0.09 & - & - & 1.14 & 0.82 \\ \text { P 6 } & 0.75 & 0.83 & 0.37 & 0.82 & 0.96 \\ \text { P 7 } & 0.15 & 0.25 & 0.81 & 0.71 & -\end{array}$

and highly polluted above $0.32 \mathrm{mg} \mathrm{kg}^{-1}$. According to this, stations analyzed in this study are considered moderately to highly polluted.

The Santos estuary constantly receives contaminated effluents, due to the proximity to industries that use mercury in some of its chemical processes. In Cubatão, the main sources of mercury are the chloroform-manufacturing units that use mercury-based electrodes (Lamparelli et al., 2001). In addition, other industries and various port terminals are sources of $\mathrm{Hg}$. However, there is still a great influence of non-point sources, such as in the rivers Santo Amaro (in Guarujá), Mariana and Piaçabuçu (in São Vicente). The influence of these industries has been studied in the last three decades. Hortellani (2008) determined the mercury concentrations in the Santos estuary with samples collected in different periods in the late 1990's and early 2000's. He used the technique of acid digestion of samples and determination by atomic absorption spectrometry - cold vapor (CV-AAS). Some stations are in proximity with the stations in this study, allowing a comparison of the results and techniques.

The report issued by CETESB (Environmental Company of the State of São Paulo) in 2001 (Lamparelli et al., 2001), regarding the pollution control program, carried out analyzes concerning the concentration of $\mathrm{Hg}$ in sediments of the Santos estuarine system. The method for quantification used by CETESB was too CV-ASS. The collections were carried out between 1997 and 1999. In Siqueira, et al. (2005), we see that other studies were carried out to analyze the concentration of $\mathrm{Hg}$ in the estuarine sediment of Santos. It is possible to observe that at two stations the concentrations obtained in the present study are higher than those found in that period: in stations 1 and 6 that have concentrations above level 2, while their equivalent stations maintain their concentrations above the level 1. However, once again station 7 presents a much lower concentration than that determined at its point of comparison in the study by Siqueira, et al. (2005). Torres, et al. (2009) determined concentrations of $\mathrm{Hg}$ in the estuary of Santos and also used the CV-ASS technique, while in Torres, et al. (2015) another technique was employed, which was Direct Mercury Analysis (DMA), based on thermal decomposition and amalgamation of mercury and similar to the present technique, it doesn't need acid digestion. Even though there were used two different methods in these previous studies (CV-AAS and DMA), results are considerable close to those of this study in which was used the TXRF. Differences in concentrations seem to be due to the dynamic processes that happen inside the estuary.

Figure 2 shows a summary of several studies conducted in the region. It is quite remarkable that the stations with the highest concentrations measured in all studies reported here are close to the channel of the port of Santos and the industries that discharge potentially contaminated effluents in the estuarine system, such as those in proximity to a chemical industry, like station 6 , and station 1 in the channel of the port, where large transport and logistics processes occur. 
The problem caused by the incorrect disposal of $\mathrm{Hg}$ in industrial effluents has been a worldwide concern for decades. The Santos lowland has been the target of several studies, due to the exponential demographic expansion to logistically strategic locations, allowing the creation of the largest port in Latin America and one of the largest industrial centers. In the 1970's and 1980's, a major socioenvironmental problem began: the levels of pollution in the city caused several cases of anencephaly in children and other diseases. Therefore, due to the need to contain the situation, several environmental monitoring measures of the region were taken and are still used today. Numerous current studies deal with the concentrations of $\mathrm{Hg}$ in human tissues in the region, in order to verify the influence of the constant discharge of polluting agents into the ecosystem and how this process has affected communities near the estuarine region (Boldrini \& Navas-Pereira, 1978; Boldrini, 1990). Mercury is related to a number of health issues. Among the toxicological effects of mercury are brain damage, which includes irritability, paralysis, blindness or insanity, as well as chromosome breakdown and birth defects (Braga, et al. 2009).

\section{CONCLUSION}

The present study made it possible to compare the concentrations of $\mathrm{Hg}$ over the last two decades in nearby sites, and to infer in later studies how the anthropic activities that pollute the estuary system have been behaving over time, and how ecosystem resilience can overcome the constant discharge of contaminated effluents. The highest levels of $\mathrm{Hg}$ found are easily related to sources that discharge potentially contaminated effluents in the estuarine system, thus signaling the great influence of anthropic activities in the process of environmental contamination by $\mathrm{Hg}$.

Despite Cold-Vapor Atomic Absorption Spectroscopy being the most applied method, the Total X-Ray Fluorescence has proven to be an interesting form of analysis since it has shown comparable concentrations and it generates fewer residues than the sample preparation used for CV-AAS methods. Furthermore, this technique is multi-element, which means that several other metals of environmental interest can be measured among mercury.

\section{Mercury Concentration in Sediments}

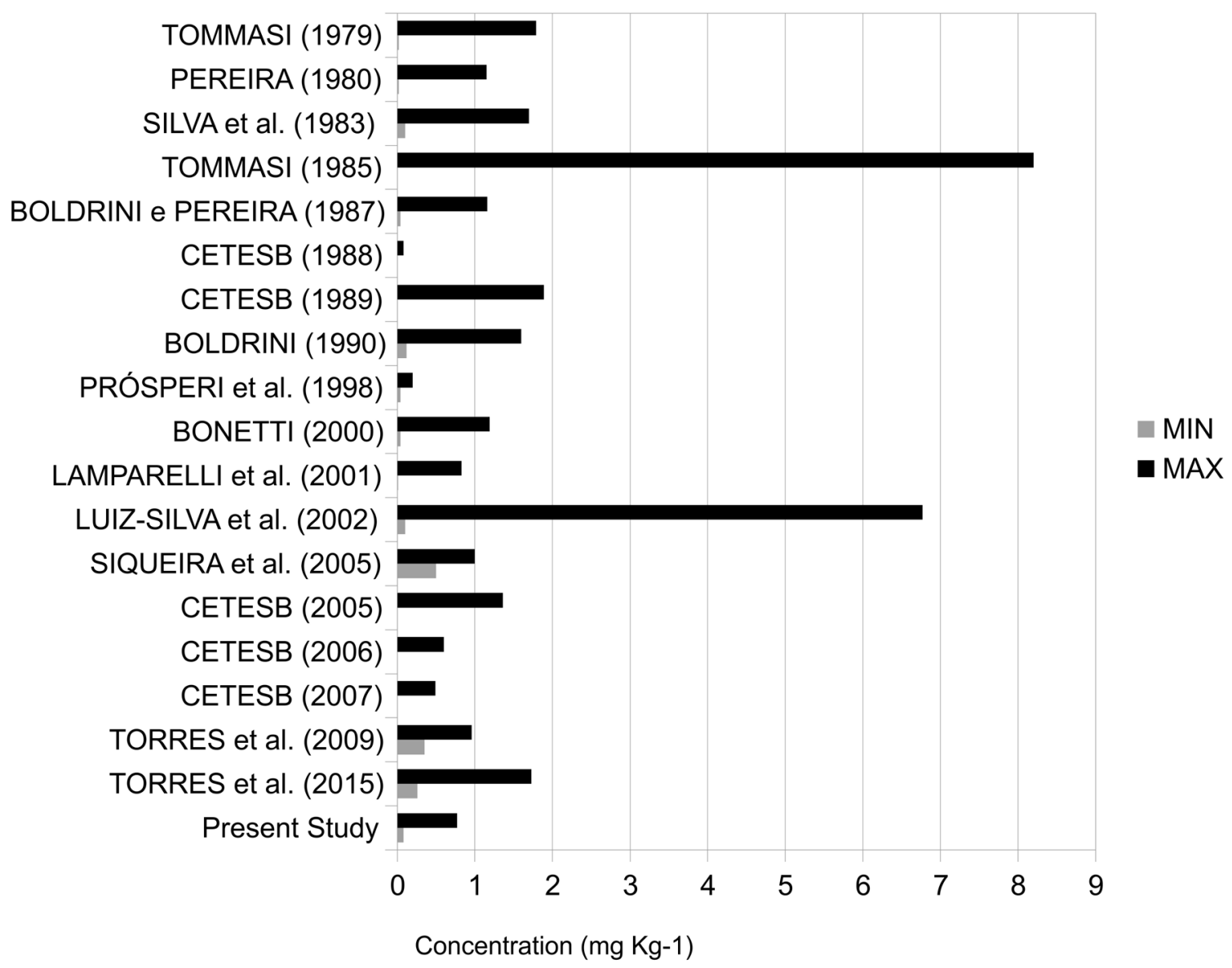

Fig. 2. Comparison between minimum and maximum ranges of $\mathrm{Hg}$ concentrations, obtained by several authors, on the sediments from the Santos Estuarine System. 


\section{ACKNOWLEDGMENTS}

Authors would like to thank the Study and Project Financing Enterprise (FINEP - Financiadora de Estudos e Projetos) in the process $n^{\circ}$ 04.13.0078.00 - Ref. 0208/12 RPMI - Unifesp for financing the Project AMBIMAR, for which this equipment was purchased.

\section{REFERENCES}

AZEVEDO, FA. 2003. Toxicologia do Mercúrio. São Carlos: RIMA; São Paulo: InterTox.

BOLDRINI, C. V \& D. NAVAS-PEREIRA. 1987. Metais pesados na Baía de Santos e São Viente: bioacumulação. Rev. Ambiente, 1(3): 188-127.

BOLDRINI, C. V. 1990. Mercúrio na Baixada Santista. In: Seminário Nacional "Riscos e consequência do uso do mercúrio". Eds. S. Racon.; L. D. Lacerda.; W. C. Pfeiffer \& D. Carvalho. Rio de Janeiro, p: 161-195

BORDON, I.C.A.C., SARKIS, J.E.S., GOBATTO, G.M., HORTELLANI, M.A. \& PEIXOTO, C.M. 2011. Metal concentrations in sediments from the Santos estuarine system: a recent assessment. J Braz Chem Soc 22 (10), 1858-1865. DOI: http://dx.doi.org/10.1590/S0103-50532011001000005

BRAGA, A.L.F. et al. 2009. Estudo Epidemiológico na População Residente na Baixada Santista - Estuário de Santos: Avaliação de Indicadores de Efeito e de Exposição a Contaminantes Ambientais. Projeto Estuário CNPq 2005/40266351 UNISANTOS • CEDEC • IBCCF/ UFRJ • NEEA - FMUSP • IPEN. 252p

CHOUERI, R.B., CESAR, A., ABESSA, D.M.S., TORRES, R.J., MORAIS, R.D., RIBA, I., PEREIRA, C.D.S., NASCIMENTO, M.R.L., MOZETO, A.A., DELVALLS, T.A. 2009. Development of site-specific sediment quality guidelines for North and South Atlantic littoral zones: Comparison against national and international sediment quality benchmarks. J Hazard Mater 170(1):320-331. DOI: https://doi.org/10.1016/j. jhazmat.2009.04.093

CONAMA - Conselho Nacional do Meio Ambiente. Resolução 454, 2012. Estabelece as diretrizes gerais e os procedimentos referenciais para o gerenciamento do material a ser dragado em águas sob jurisdição nacional.

HORTELLANI, M.A., SARKIS, J.E.S., ABESSA, D.M.S. \& SOUSA, E. 2008. "Avaliação da contaminação por elementos metálicos dos sedimentos do Estuário Santos-São Vicente." Química Nova 31.1: 10.
LAMPARELLI, M.L., COSTA, M.P., PRÓSPERI, V.A., BEVILACQUA, J.E., ARAÚJO, R.P.A., EYSINK, G.G.L. et al. 2001. Sistema estuarino de Santos e São Vicente. Relatório Técnico CETESB, São Paulo.

LUIZ-SILVA, W., MATOS, R.H.R. \& KRISTOSH, G.C. 2002. Geoquímica e Índice de Geoacumulação de Mercúrio em Sedimentos de Superfície do Estuário de Santos - Cubatão (SP). Quim. Nova, Vol. 25, No. 5, 753-756

LUIZ-SILVA, W., MATOS, R.H.R.; KRISTOSH, G.C. \& MACHADO, W. 2006. "Variabilidade espacial e sazonal da concentração de elementos-traço em sedimentos do sistema estuarino de Santos-Cubatão (SP)". Quim. Nova, Vol. 29, No. 2, 256-263.

PRÓSPERI, V.; G. G. J. EYSINK \& L. M. SAITO. 1998 Avaliação do grau de contaminação de sedimentos ao longo do canal de navegação do porto de Santos. Relatório Técnico da CETESB/ SP, 33p.

SILVA, O.R., \& GOMES, M.B.M. 2012. Impactos das atividades portuárias no Sistema Estuarino de Santos. Revista Metropolitana de Sustentabilidade, V.2, N.2

SIQUEIRA, G. W., BRAGA, E. DE S., PEREIRA, S.F.P. \& SILVA, E. 2005. Distribuição do mercúrio em sedimentos de fundo no Estuário de Santos- SP/Brasil. Geociências, Minas Gerais. Vol 58, n.4: p 309-316

TOMMASI, L. R. 1979. “Considerações ecológicas sobre o sistema estuarino de Santos (SP).”Honorary Professor Thesys. Universidade de São Paulo, Instituto Oceanográfico

TOMMASI, L.R. 1985. Poluição por mercúrio na água e sedimentos de fundo da Baía e Estuário de Santos e de São Vicente (SP). Rev. Ciên. Cult., 35(6):998-1001

TORRES R.J., ABESSA, D.M.S., SANTOS, F.C., MARANHO, L.A., DAVANSO, M.B., NASCIMENTO, M.R.L. \& MOZETO, A.A. 2009. Effects of dredging operations on sediment quality: Contaminant mobilization in dredged sediments from the Port of Santos, SP. Brazil. J Soil Sed 9(5):420-432. DOI: http://dx.doi. org/10.1007/s11368-009-0121-x

TORRES, R.J., CESAR, A., PASTOR, V.A., PEREIRA, C.D.S., CHOUERI, R.B., CORTEZ, F.S., MORAIS, R.D., ABESSA, D.M.S., NASCIMENTO, M.R.L., MORAIS, C.R., FADINI, P.S., DELVALLS CASILLAS, T.A. \& MOZETO, A.A. 2015. A critical comparison of different approaches to sediment-quality assessments in the Santos estuarine system in Brazil. Arch Environ Contam Toxicol 68 (1), 132-147. DOI: http://dx.doi. org/10.1007/s00244-014-0099-2

YOUNG, V.F. 2017. Análise da intrusão salina no Estuário de Santos (SP) com foco no rio Diana. Course Completion Work in the Interdisciplinary Bachelor of Science and Technology of the Sea. Federal University of São Paulo. 28p. 